Student Success

ISSN: 2205-0795

Volume 6, Issue 2, pp. 1-8

August 2015

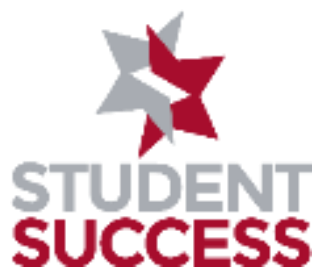

Feature

\title{
Students, Transitions, Achievement, Retention, Success: STARS Invited Panel
}

\author{
Karen Nelson and John Clarke
}

Student Success

\section{Abstract}

The Invited Panel Session at the inaugural STARS Conference concluded the formal presentations for the event. At this session, invited STARS from the tertiary sector shared with delegates their personal thoughts concerning the messages and insights gained from the conference experience. The Panel Session also provided delegates with the opportunity to respond and share their views in order to consolidate learnings. Delegates were challenged to give thought to their intended activities and actions in their own settings based on their experiences at the conference. For the purposes of this feature, the editors have summarised and edited the transcript to present the key points of each discussion, including questions and comments from delegates. Panel members have approved the authors' interpretations of their comments.

Please cite this article as:

Nelson, K. \& Clarke, J. (2015). Students, Transitions, Achievement, Retention, Success: STARS Invited Panel. Student Success. 6(2). 1-8. doi: 10.5204/ssj.v6i2.301

Student Success: A journal exploring the experiences of students in tertiary education

(cc) $\mathrm{Br}$ This work is licensed under a Creative Commons Attribution 4.0 Licence. As an open access journal, articles are free to use, with proper attribution, in educational and other non-commercial settings. ISSN: 2205-0795 


\section{Introduction}

The concluding formal session of the inaugural STARS Conference held in Melbourne, Australia in early July 2015 was a panel discussion, chaired by Ron Oliver, Deputy Vice-Chancellor (Teaching, Learning and International) and Professor of $e$-learning at Edith Cowan University in Western Australia.

The Panel members: ${ }^{1}$ James Arvanitakis, Professor of Humanities and Head of The Academy, University of Western Sydney; Marnie Hughes-Warrington, Deputy ViceChancellor (Academic) The Australian National University; Sally Kift, Deputy Vice-Chancellor (Academic) James Cook University; Karen Nelson, Pro Vice Chancellor (Students) University of the Sunshine Coast and Beverly Oliver, Deputy Vice-Chancellor (Education), Deakin University - themselves a constellation of STARS-each focussed on one of the STARS themes:

\section{Students Marnie Hughes- Warrington \\ Transitions Sally Kift}

\section{Achievement Beverly Oliver}

\section{Retention Karen Nelson}

\section{Success James Arvanitakis}

This summary of the discussion highlights the key aspects of each theme as identified by the panel members and the audience.

\section{Students - Marnie Hughes- Warrington}

As I have gone from room to room during this conference, the poignancy and the power of the individual student experience has been obvious.
One of the great things about this conference is I think it's the only one I can think of where both professional staff and academic staff stand next to one another. Both groups talk from the ground about their experiences and the thing that unites all is a love of students.

We all have experienced the moments when we've sat in meetings at university and people have been going on in strange ways, making peculiar decisions, making bizarre assumptions and a student just cuts through it-they speak up, they speak on behalf of themselves and other students and they remind us why we're there. They speak with profound rationality from experience and they remind us what we're here for. So the great thing about this conference is that it also privileges students and what we're in the game for ... it's very special.

Take the power and the positivity of this back to your institution and remind people that students are the primary reason we're there because we're institutions of potential. We do research because we believe something new is going to happen. We look after students because we believe something new is going to happen. It's a profound part of what we do.

Comment from Ron Oliver: When the word STARS was chosen for the conference, starting with students was so important and I think you can see why.

Question from Craig Barrie, La Trobe University: To the theme of students ... I've observed, noticed a theme across many of the presentations - students as co-creators and students as partners, in everything from governance through to curriculum. I was just wondering if anyone wanted to make a comment about what they think is the most exciting development that's going on for them at

\footnotetext{
${ }^{1}$ The CV of each panel member and session chair Ron Oliver is provided as part of the Conference proceedings. See

pages 257-260 of http://unistars.org/papers/STARS2015.pdf
} 
the moment around students as partners or students as co-creators?

Response from Marnie HughesWarrington: We're considering getting students to make MOOCs (Massive Open Online Course) [Added by authors] for us. If we think our teaching is great then the best people to deliver that globally are our students, not to let them teach as assistants, but actually to make them. There's no better test of their qualities than that.

Response from James Arvanitakis: I've developed this program called the Academy at the University of Western Sydney ${ }^{2}$, which is a program that brings together the high performing students from the different disciplines, so nursing students, medical science students, law students, business students, humanities students, they all come together in a program that was designed in part, by students themselves.

Comment from Janet Taylor, Southern Cross University: For me learning is at the heart of what we're doing here and I'm wondering where learning fits in and weaves through all those things. So for me learning - I mean students can't be uncoupled from their learning.

Comment from Tristan Dimmock, Australian National University: I wanted to make a comment about perhaps the rising expectations on students and I think a lot of the talks around here have been on extra-curricular or cocurricular things that are being provided or students are expected to do.

Response from Marnie Hughes-Warrington: One of the challenges for us is to take the traditional elements of the co-curriculum that we think are valuable and actually build them into the curriculum.

\section{I feel like a winner because I got 'students'}

Marnie Hughes-Warrington
Comment from Beverly Oliver: I think cocurriculum is code for "not serious" or as important as what we call the curriculum. I think it's a false division that we should grow out of as universities.

Comment from Jill Lawrence, University of Southern Queensland: Some students are actually working first and studying - they're working full time and they think they can study full time too and that's one of the expectations they come with. So a clash for them is in understanding that there might need to be more of a commitment to study. There's a socioeconomic divide at the root of this.

\section{Transitions - Sally Kift}

I think it's important for us to understand that "Transitions" is an international agenda [item] at the moment. Students are very much cocreators of the curriculum. We need to think about how we might better enable student cocreation. If we were going to try and conceptualise transitions and I think one of the themes over the course of this conference, which has been a very good and healthy theme, is around mental health and wellbeing for students, and part of the conversation we need to have with students is: "What is this transition thing that you're going through"?

What I also heard over the course of the Conference is great intentionality about managing the transitions over the course of the student lifecycle; and a quite deliberate attention to the part of the lifecycle that looks at the pre-university experience, which we know

\footnotetext{
${ }^{2}$ Academy at the University of Western Sydney http://theacademy.edu.au/
} 
is so important and shapes much of what students bring to university. Our role is to give students an overall sense of coherence and achievement as they go through their transitions: forwards, backwards, sideways or whatever.

We've been assisted most recently with the Critical Interventions Framework ${ }^{3}$ which is making very clear to us that there are deliberate points at which we can intervene with great intention and effect over the course of the student lifecycle. The elements of Transition students' achievement of course [program] learning outcomes.

When I think about what was intended by the idea of the STARS Conference, we wanted conversations about these multiple pathwaysin, through and out. The last thing I wanted to say was we need to acknowledge ourselves our own transitions. We've made the transition from focusing on first year; and all the old colleagues and new colleagues are in the room are engaging with that. That's a successful transition.

\section{... when I think about what was intended by the Conference, we were talking about multiple pathways, in, through and out.}

Sally Kift

Pedagogy apply equally to the final year because students are still in transition, but they're transitioning out. In final year, students are still very diverse, but diverse in different ways. They come in to the final year via different pathways and they're going out through different pathways. The Transition Pedagogy ${ }^{4}$ principle of design is still absolutely important but its focus is more on engendering a sense of cohesion and integration for students as they go out. The engagement principle focusses on students engaging with their professional identity and alumni. Assessment for future learning: so that new graduates are able to selfand peer-assess in the real world. Evaluation and monitoring: also critical because in the TEQSA environment we need to demonstrate
Comment from Paul Fenton, Auckland University of Technology: One of the core facets that we're focusing on is actually for students to retain their cultural identity. Indigenous voices belong everywhere. One of our keys to success has been that students don't lose their cultural identity. We do not want to homogenise or vanilla-ise or, have a great big melting pot of people. We talk about diversity but I think that Indigenous' voices need to be heard and are given greater prominence.

Response from Sally Kift: What I'm hearing more and more as we move to embed transitions in curriculum is around inclusive curriculum design and allowing students to see reflected in the curriculum the experiences of people just like them ... but we've still got a long way to go. Both the Australian OLT and New Zealand's Ako Aotearoa have developed, and continue to develop, great resources to assist us with addressing the needs and perspectives of

\footnotetext{
${ }^{3}$ A report designed to assist in advancing equity in Australian higher education including the Critical Interventions

Framework https://www.ncsehe.edu.au/publications/critical-interventions-framework/

4 Transition Pedagogy http://transitionpedagogy.com/
} 
Aboriginal and Torres Strait Islander students and Māori and Pasifika students. ${ }^{5}$

Response from Marnie Hughes-Warrington: We have a shameful statistic that shows how few Indigenous academic staff there are in the Australian sector. One of the other transitions is supporting young Indigenous staff as they come in. There is a generational shift happening and we have an obligation [not only] to support new Indigenous staff members but also to keep the very talented Indigenous staff we already have.

\section{Achievement - Beverly Oliver}

A for achievement, A for assessment and A for attributes. So I'm going to mix those three things into this little strand. Achievement to me is learning; it's discipline knowledge plus all the other skills and attributes that make us prepared for our chosen future, whatever that is. I think we often fall into the trap of thinking we're talking school leavers: Many are but many are "35 with three kids and a mortgage and a job"; mature age learners who are now coming to university because their kids had been through and now it is their turn.

Marks and grades don't capture learning before university or at university. Not all learning is measured or formally credentialed but we keep credentialing and measuring and we give out transcripts with marks, grades and credits on them and the things we just talked about-cocurriculum and all the other really fantastic things-we often relegate to some other certificate thing.
One of the things we're trying at Deakin University is credentialing what you would normally call graduate attributes. So life skills, all those really important things, and it comes through the course curriculum. We're going to use digital badging technologies to warrant at a whole of course (program) level and give you an enduring credential that you are indeed an outstanding communicator, team worker-all the usual graduate attribute type things.

In her session at this conference, Betty Gill ${ }^{6}$ (Associate PVC [Academic] University of Western Sydney) talked about assessment mapping in courses. This absolutely has to be

\section{.. despite any technology that's ever invented, the fundamentals of really good teaching and learning don't change}

Beverley Oliver done and systematically I think. I think assessment is the heart of the matter. And the context was that overall, we're not that great at assessment. We're not experts in assessment and I agree with that. The point is that in the era of MOOCs and Google and IBM Watson and everything else that's in the digital zone, we're not going to need to focus on content alone for much longer. The only thing we will have left is assessment, feedback and credentialing. That's the business we're already really in so we better get good at it really quickly. I'll finish on the idea that, if assessment is what counts, then we need to find new ways of re-imagining the assessments so that we also build in those

\footnotetext{
${ }^{5}$ See reports and resources from current and past projects and fellowships dedicated to Indigenous perspectives and practices from the Australian Government's Office for Learning and Teaching (OLT) and Ako Aotearoa's National Centre for Tertiary Teaching Excellence in New Zealand http://www.olt.gov.au/about-olt https://akoaotearoa.ac.nz/
}

${ }^{6}$ Betty Gill's Conference paper is published in full in this issue of Student Success (Volume 6, Issue 2) August 2015 
communication, information literacy, teamwork, global citizenship [skills]... It can be done, it's not easy. And focus not on testing and measuring only but getting students to have the evidence they can do those things.

Comment from Jeanne Young from Flinders University: I think it is a really important thing to remember and I try to remind students that when they come in about their assessment marks.

Response from Beverley Oliver: I think we have invented a currency and student trade in that

It doesn't matter whether you're an academic staff member or an administrator or an academic skills advisor, we all need to respect the contributions that each and every one of us makes

Karen Nelson

spend on our campuses or in our university areas that they can't get somewhere else.

Comment from Beverley Oliver: I guess where I was going was that what we must focus on is not being providers of content as much as we have been but on assessing, credentialing and giving interactive encouraging feedback.

\section{Retention - Karen Nelson}

I am passionate about retention rates-not because it's a number that we use to measure how well we are doing-but because it represents how well we do in fulfilling our promise to those students who enter our institutions, and how well we do in fulfilling that promise to their families, their communities and the bigger world that they come from. I'm passionate about retention because for those students it means a better way into the future, retention provides a pathway into the future and attrition, which obviously is the other

currency ... I don't think we can throw them out, I think we have to keep them [marks] but make them more meaningful. But the As and the Bs are simply codes and signals that we all try and read.

Comment from Jo McKenzie, University of Technology, Sydney: We had a great student workshop at UTS not so long ago, they were saying they still want that university experience. They want that feeling of coming to university and being a student. Now, of course, these were young undergraduates that we had but I think we need to maintain sight of "What is that university experience?" so all our students can really make the most of the time that they side of retention, is about hopes and dreams that are dashed, it's about a poorer future and it's about poorer long term outcomes and to me this means that we're not doing our job properly. Irrespective of who those students are and irrespective of their backgrounds, irrespective of their $\mathrm{ATAR}^{7}$ what they know when they come and what effort we need to put in, we're just not doing our job properly if a lot of our students leave before those promises that we make to them have been fulfilled.

There are 126,000 reasons why students leave our institutions but they're retained, as you know, if they're learning, if they're feeling enabled and in control of their learning, if they're being challenged by the content that

\footnotetext{
${ }^{7}$ ATAR: The Australian Tertiary Admission Rank (ATAR) is the primary criterion for entry into most undergraduateentry university programs in Australia.
} 
they are learning, if they feel well supported during that learning process, and if we show them and demonstrate to them the kinds of behaviours that lead to effective-and ineffective-behaviours in terms of their learning. We have control over creating environments in which student learning leads to higher levels of engagement and high levels of engagement lead to further learning and to students being successful.

My point is that we control the environment, all of us. Professional staff, academic staff, administrators, people who are learning support advisors, our Indigenous support groups. We are all responsible.

Some of the presentations at this conference have been around some of those other important Rs that are connected with the big $\mathrm{R}$ of retention:

Resilience. It's already been mentioned by the panel and many of us are acutely aware of resilience as a contributor to student's transitions and their achievement;

Respect, for Identity. Respect for our fellow academics, respect for the disciplines and the absolute essential nature and inherent attributes of learning in a discipline and of connecting with peers within a discipline, all of whom have come to study together;

Recognition of what has gone before in the students' learning journey; recognition of what our students bring with them. Recognising that our students are not just numbers sitting in classes, but they're individuals with their own hopes and fears and recognising that the experiences and knowledge they bring with them is incredibly valuable and important to their futures. creating an environment where the students can succeed in their life journey no matter where they start, no matter what obstacles they face

James Arvanitakis
My final R is for:

Returning students who have tried to engage but it hasn't been right or the right time for them, but they return to our institutions because they know that there are pathways open to them. So, the courage of the returning student, the second chance learner. Those students who later on in their lives, and I was one of them, find out that going to university is fantastic and it's a utterly rewarding - another $\mathrm{R}$ - experience.

$\mathrm{R}$ is for retention. It's important because of what it represents to the individuals and their families and communities. Being responsible for creating the environment in which students engage in their learning that leads to success for those students. Recognising the importance of resilience, respecting each other and our students, recognising what our students bring with them and remembering that there are returning students and second chance learners. Finally, I think trying to explain away poor retention as "good attrition" is quite frankly, a bit of a cop-out.

\section{Success- James Arvanitakis}

What does success look like? Well I'll share a story. We have a student, who was a victim of domestic violence, a very abusive relationship, for a number of years. I share her story because she has it in the public domain and given us permission to do so. 
One day after a particularly bad episode, she picked up her two children, a toddler and another very young child, and left the home with two black eyes and a broken jaw. And she made her way to a shelter. A worker gave her a leftover bottle of body wash, and that sevenminute shower was the thing she looked forward to every day for she felt pampered. She eventually got her life together and moved on and established an organisation called the Beauty Bank (www.thebeautybank.org) where she collects unused beauty products, gifts people don't want and so on and she puts them in little care packs and drops and delivers them to different centres around Sydney. (The student) came to university a couple of years ago as a mature age student, terrified, not thinking she belonged. About three months ago, she walked up to the CEO of a football club "If you want to have a gendered program in your football team I'm the woman to lead it." And that's success, yeah? Her university journey has been a significant part of that and she's also just received a scholarship to spend some time at Harvard-based conference. And that for me is success, you know, a scared, terrified person who felt like a fish out of water overcoming all those odds.

That's what we do, that's beyond content, creating an environment where the students can succeed in their life journey no matter where they start, no matter what obstacles they face, assisting them to build those tools to confront those challenges.

We've spoken about various forms of success: Transitions from high school or as mature age students into a University program. The transition from second year into third year and then from there into professional lives, that's success. But then there's also other levels of success and it's not just success with our students and their experiences but the way that hopefully we teach beyond the classroom to recognise the conversations that we have in the classroom are also the conversations that are had in pubs and clubs and at home. If students can build a language to talk about the need for recognition of Indigenous Australians or the need for justice for refugees and so on, then that's success.

Then there's also our success, what it means to us as educators? I think success ultimately for us is, not to sound too weird, but one of the things that we experience is sessions such as this and other sessions that have taken place during this conference: I've been looking at the way that people's eyes light up when they talk about engaging with students. That is amazing and it reminds me why I became an academic.

When we capture those moments and we share it amongst ourselves in a really generous and open way, then for me that's success.

Final comment from Ron Oliver: As I was listening to James speaking, I thought: This is really what we're here about isn't it? It's sort of like the big $\mathrm{S}$ at the end, everything that we've done over the past two days. I keep coming back to generosity of spirit you see when you think about the delegates and the people you work with. Respect, that's what I saw so much of at this conference, and it was [not only] respect for each other but also incredible respect for our students. And that might be a wonderful way to finish off and to say thank you to our panel.

\section{STARS Conference http://unistars.org/}

\section{References}

Arvanitakis, J., Hughes-Warrington, M., Kift, S., Nelson, K., Oliver, B., \& Oliver, R. (2015, July). Transcript of the STARS Invited Panel: A discussion of the themes of the STARS Conference. Melbourne, Australia. 